\title{
Myosin-Driven Intracellular Transport
}

\section{Margaret A. Titus}

Department of Genetics, Cell Biology and Development, University of Minnesota, Minneapolis, Minnesota 55455

Correspondence: titus004@umn.edu

\section{SUMMARY}

The delivery of intracellular material within cells is crucial for maintaining normal function. Myosins transport a wide variety of cargo, ranging from vesicles to ribonuclear protein particles (RNPs), in plants, fungi, and metazoa. The properties of a given myosin transporter are adapted to move on different actin filament tracks, either on the disordered actin networks at the cell cortex or along highly organized actin bundles to distribute their cargo in a localized manner or move it across long distances in the cell. Transport is controlled by selective recruitment of the myosin to its cargo that also plays a role in activation of the motor.

\section{Outline}

1 Introduction

2 The transport myosins-Basic features

3 Intracellular transport of secretory and endocytic vesicles

4 Diseases caused by defects in actin-based organelle transport

5 RNA trafficking
6 Movement along actin bundles

7 Long-distance transport

8 Cytoplasmic streaming in plants

9 Conclusion

References 


\section{INTRODUCTION}

A remarkable feature of cells is the dynamic and often robust movement of their internal contents. Intracellular motility is used to position organelles where they are needed, such as targeting secretion to the apical regions of cells lining a lumen. The major cytoskeletal filament systemsactin and microtubules-serve as the tracks for movement of cellular cargo that is largely driven by their associated cytoskeletal motors, kinesins, dynein, and myosins. A variety of cellular content is transported, including intracellular vesicles such as endosomes and exosomes, organelles such as melanosomes or mitochondria, and particles such as ribonucleoproteins (RNPs). In metazoan cells, transport can be divided into two parts-long-distance movement along microtubules (reviewed by Barlan and Gelfand 2016) and relatively short-range transit along actin filaments. The polarized organization of the microtubule system, with many slow-growing ends embedded in the centrosome and the fast-growing ends extending all the way out to the periphery, provides tracks for movement to the cellular periphery and back into the center of the cell. Although these provide efficient highways for cargo, a local distribution system is needed, and that is provided by the actin cytoskeleton.

The cytoskeletal actin network is generally not polarized and, instead, filaments are randomly oriented in the cell, allowing for the movement of cargo all throughout the region in which filaments are found (for review, see Svitkina 2016). However, there are select regions of the cell in which actin is arranged in a more orderly manner. The actin filaments in cortical regions immediately beneath the plasma membrane are generally arranged with their barbed (or fast-growing) ends oriented toward the plasma membrane, providing a path for myosin-dependent movement of cargo either to or from the plasma membrane, based on the directionality of the associated motor. Specialized protrusive structures comprising parallel bundles of actin with their barbed ends at the membrane and pointed ends at the base, such as filopodia, stereocilia, and microvilli, also serve as cellular "superhighways" for cargo that is targeted for delivery within these structures, anchored at their tip or targeted for secretion.

The ability of cargo to move along either filament system means that intracellular transport is coordinated in a general sense. Intracellular vesicles or organelles have been shown to move along one filament system and then switch over to the other (for examples, see Rodionov et al. 1998; Rogers and Gelfand, 1998; Schuster et al. 2011; Schroeder et al. 2012). The mechanism by which an organelle can move along one filament type and then switch to another or change directionality when moving on a filament is not yet well understood. It certainly requires that the appropriate motors are activated in the regions of the cell in which the microtubules and actin filaments overlap at the site of cargo transfer, and/or else already active motors might engage in a tug-of-war and the greater power or number of one motor type might win over the other. It should be noted that, in addition to translocation via motor-driven motility along filaments, actin polymerization can also power the intracellular movement of vesicles, typically endocytic vesicles, and even pathogenic bacteria, and that this occurs independently of microtubule motors. The focus of this review is on myosin-dependent movement of cargo along actin filaments. Selected examples will be presented to highlight the diversity and shared features of motor-driven transport along actin filaments in different cell types.

\section{THE TRANSPORT MYOSINS - BASIC FEATURES}

A variety of different myosins transport cargo within cells (reviewed by Sweeney and Holzbaur 2016). One key feature of these motors is their distinctive carboxy-terminal tail regions that bind to specific partner proteins to target the myosin to a particular cellular location or organelle. Another property of transporters is their ability to move continuously along actin filaments, typically on dimerization or multimerization. The myosin $\mathrm{V}$ family of myosins (reviewed in Hammer and Sellers 2011) are among the most widely used motors for actin-based transport and they are found in a diverse set of organisms ranging from amoebae to yeast to human, suggesting that they are among the most ancient of actin-dependent translocators. Myosin Vs have roles in the actin-based motility of organelles, vesicles, and RNPs, and a wide range of studies of the intracellular transport of these cargos have revealed several fundamental aspects of myosin-dependent movement along actin within a cell.

All known myosins with the exception of one, myosin VI, move in the same direction on the actin filamenttoward the barbed end. Given that actin filaments within the cell are generally organized in a random fashion, the barbed end motors are all perfectly well-suited for distributing cargo throughout a network of filaments. However, in those regions of the cell in which actin filaments have a defined orientation, such as at the periphery where they are oriented with their barbed ends toward the membrane, barbed end-directed myosins, such as myosin V, will move cargo toward the plasma membrane, whereas the pointed end-directed myosin VI would work in opposition to transport vesicles away from the plasma membrane and into the interior of the cell. The same would be true for the movement of myosins along the parallel actin bundles found in filopodia, microvilli, and stereocilia. 
The actin filaments themselves can also have an impact on translocation. For example, myosin Ic plays a role in the transport of vesicles containing GLUT4 in adipocytes, but it is unable to bind to actin filaments with the tropomyosin Tpm3.1 bound. Thus, this myosin tends to selectively drive cargo transport along filaments without tropomyosin (Kee et al. 2015). Regulating the levels of Tpm3.1 in the cortex might provide the cell with a mechanism to control the transit of GLUT4 vesicles in that region. The nucleotide state of an actin filament can also play a role in regulating myosin movement. Myosin Va takes more steps on a growing actin filament (the actin monomer has ADP.P ${ }_{\mathrm{i}}$ bound) than on older filaments (ADP actin) (Zimmermann et al. 2015). In contrast, myosin VI prefers "older" ADP actin filaments. These differences in run length correlate with the directionality of each motor and could play a role in favoring the movement of one motor or another in regions of the cell with more stable, older filament networks versus regions in which the actin filaments turn over rapidly.

The activity of transport myosins is tightly regulated to prevent the cargo-attached motor from interacting with actin filaments until it is at the correct location and to avoid unproductive interactions with actin filaments when the myosin is not bound to cargo. A major mode of regulation is through autoinhibition. In the case of myosin $\mathrm{V}$, as well as myosin VIIA and myosin X, the myosin is typically maintained in an "OFF" state when the globular tail domain (GTD) is folded over and interacts with the motor to inhibit activity. Conserved residues on both the motor domain and tail of myosin $\mathrm{V}$ mediate this interaction (Liu et al. 2006; Thirumurugan et al. 2006; Li et al. 2008; Nascimento et al. 2013). Mutation of these tail residues in yeast myosin V, Myo2p, results in a constitutively active motor (Donovan and Bretscher 2015).

Cargo binding to the myosin tail unfolds the myosin and relieves inhibition of the motor. Coupling cargo binding to activation ensures that motors are only turned on when cargo is available and ready for transport. Several studies show that myosin $\mathrm{V}$ is activated in vivo on binding of a cargo adaptor to the GTD. For example, the adaptor melanophilin increases the physiological actin-activated $\mathrm{Mg}$-ATPase and in vitro motility of myosin $\mathrm{Va}$ ( $\mathrm{Li}$ et al. 2005; Sckolnick et al. 2013). Melanophilin binding switches myosin $\mathrm{V}$ from the closed inhibited conformation to a fully extended active conformation (Yao et al. 2015). This mechanism of activation for cargo transport is likely used by other myosins. Autoinhibition can also be overcome by myosin binding to membranes by direct interaction of the tail with lipids (typically phosphatidylinositol(4,5)-bisphosphate, PIP2, or phosphatidylinositol $(3,4,5)$-trisphosphate, PIP3). In the case of myosin X, lipid binding unfolds the autoinhibited myosin and turns on its activity (Umeki et al. 2011). Another mechanism for activating myosins could be through $\mathrm{Ca}^{2+}$ binding to calmodulin light chains bound to the lever arm region that unfolds the myosin (see below).

Transport by myosins can also be activated, or significantly enhanced, by converting a monomer to a dimer by its binding partner(s), enabling the motor to move processively along actin. Cytosolic myosin VI is a monomer; however, binding of its partners optineurin or Dab2 to the tail dimerizes the motor, which is then able to move long distances along actin (Phichith et al. 2009; Yu et al. 2009). Similarly, myosin VIIA is a monomer and, when expressed in COS7 cells, it is largely cytosolic. Coexpression with its binding partner MyRIP dimerizes the motor, which can then translocate along actin filaments of a filopodium to the tip (Sakai et al. 2011).

Another mode of modulating transport is through the ability of myosins to sense and respond to forces. High load can significantly slow the mechanochemical cycles of some myosins, converting them to an anchor. For example, just 1 picoNewton $(\mathrm{pN})$ of force significantly slows ADP release from myosin $\mathrm{Ib}$, increasing the time it remains bound to actin (Laakso et al. 2008), and thus it might not be suitable as a transporter. In contrast, $1-4 \mathrm{pN}$ of force increases the processivity of myosin Ic (Greenberg et al. 2012).

Although the different modes of regulating myosins that transport cargo are now well understood at the molecular level, much remains to be learned about how these mechanisms operate in vivo. Many questions remain concerning how myosins are recruited to the appropriate cargo or activated at the right time and the right place, especially during switching from one track to another, and how these motors are able to propel this cargo along the dense actin network.

\section{INTRACELLULAR TRANSPORT OF SECRETORY AND ENDOCYTIC VESICLES}

Vesicles moving through the secretory and endocytic pathways must typically transit through the actin-dense cortex during internalization, recycling, and secretion. One motor implicated in this movement is myosin $\mathrm{V}$, and the key first step for transport through the cortex is recruiting the myosin to the vesicle when and where it is needed. The Rab family of small GTPases and their effectors play a major role in motor recruitment to specific types of vesicles, because each is marked by a specific Rab (Hutagalung and Novick 2011; Jean and Kiger 2012). Myosin V isoforms are recruited to a Rab-containing vesicle either by direct binding of their GTD to the active Rab (GTP form) or to its Rab effector, or to both (Hammer and Sellers 2011). Alternative splicing in the tail can increase the targeting specificity of 
M.A. Titus

myosin V. Structural studies of Rab and Rab effectors bound to mammalian myosin $\mathrm{V}$ tails have revealed the basis for Rab selectivity and how a Rab and its effector might bind simultaneously (Pylypenko et al. 2013; Wei et al. 2013).

Increasing $\mathrm{Ca}^{2+}$ levels locally (to $\geq 10 \mu \mathrm{M}$ ) changes the conformation of myosin V (Krementsov et al. 2004; Li et al. 2004; Wang et al. 2004), but these concentrations of $\mathrm{Ca}^{2+}$ also reduce the motile activity because of dissociation of calmodulin light chains from the neck region (Cheney et al. 1993). This suggests that $\mathrm{Ca}^{2+}$ activation of myosin $\mathrm{V}$ would not be an effective mode of activating this motor in vivo. Instead, increasing $\mathrm{Ca}^{2+}$ levels might slow or inactivate the cargo-bound motor.

Membrane receptors and channels are recycled back to the plasma membrane after internalization to maintain the normal physiological activity of a cell. After internalization, a receptor or channel is sorted into a recycling endosome for return to the plasma membrane. Myosin $\mathrm{Vb}$ moves the recycling endosome along actin filaments into position to dock for fusion with the plasma membrane (Fig. 1) (Hammer and Sellers 2011). The GTD of myosin Vb has binding sites for both the small GTPase Rab1la and its effector FIP2, which recruits myosin $\mathrm{Vb}$ to recycling endosomes in both polarized and nonpolarized mammalian cells (Schafer et al. 2014). Interaction of myosin $\mathrm{Vb}$ with both Rab1la and FIP2 stabilizes the complex on the vesicle. Myosin $\mathrm{Vb}$ is subsequently released from the recycling endosome when Rab1la is deactivated, presumably by a GTPase-activating protein (GAP) that stimulates hydroly- sis of the bound GTP. The absence of myosin Vb function causes major defects in receptor recycling and results in decreased endocytosis (Roland et al. 2011). These interactions of myosin $\mathrm{Vb}$ with endosomes are similar to those of myosin Va with its adaptor complex of Rab27a and melanophilin (Hammer and Sellers 2011).

Elegant inducible recruitment strategies to manipulate motor-driven transport provide strong support for the role of myosin $\mathrm{V}$ in the transfer of cargo from microtubulebased transport to transport in the cortical actin cytoskeleton (Kapitein et al. 2013; van Bergeijk et al. 2015). Peroxisomes tagged with red fluorescent protein (RFP) normally move little in COS7 cells, but move robustly to the cell periphery if a kinesin motor is recruited to the organelle by fusing a peroxisome-targeting sequence (PEX) to its tail. Myosin $\mathrm{Vb}$ was inducibly recruited to the peroxisomes with bound kinesin using an adapter system consisting of FK506-binding protein (FKBP) on the peroxisome and FKBP12-rapamycin binding domain labeled with green fluorescent protein (GFP-FRB) replacing the cargo-binding GTD of myosin $\mathrm{Vb}$. Addition of rapalog (an analog of rapamycin) induced the reversible association of FRB with FKBP and recruited myosin $\mathrm{Vb}$ to peroxisomes. Peroxisomes with both kinesin and myosin $\mathrm{Vb}$ moved rapidly toward the periphery of the cell, but movement slowed in the cortical regions in which individual peroxisomes moved irregularly with short pauses. These observations show the ability of myosin $\mathrm{V}$ to dominate over kinesin to move organelles into the cell periphery and then drive local delivery of vesicles to the plasma membrane in spite of the

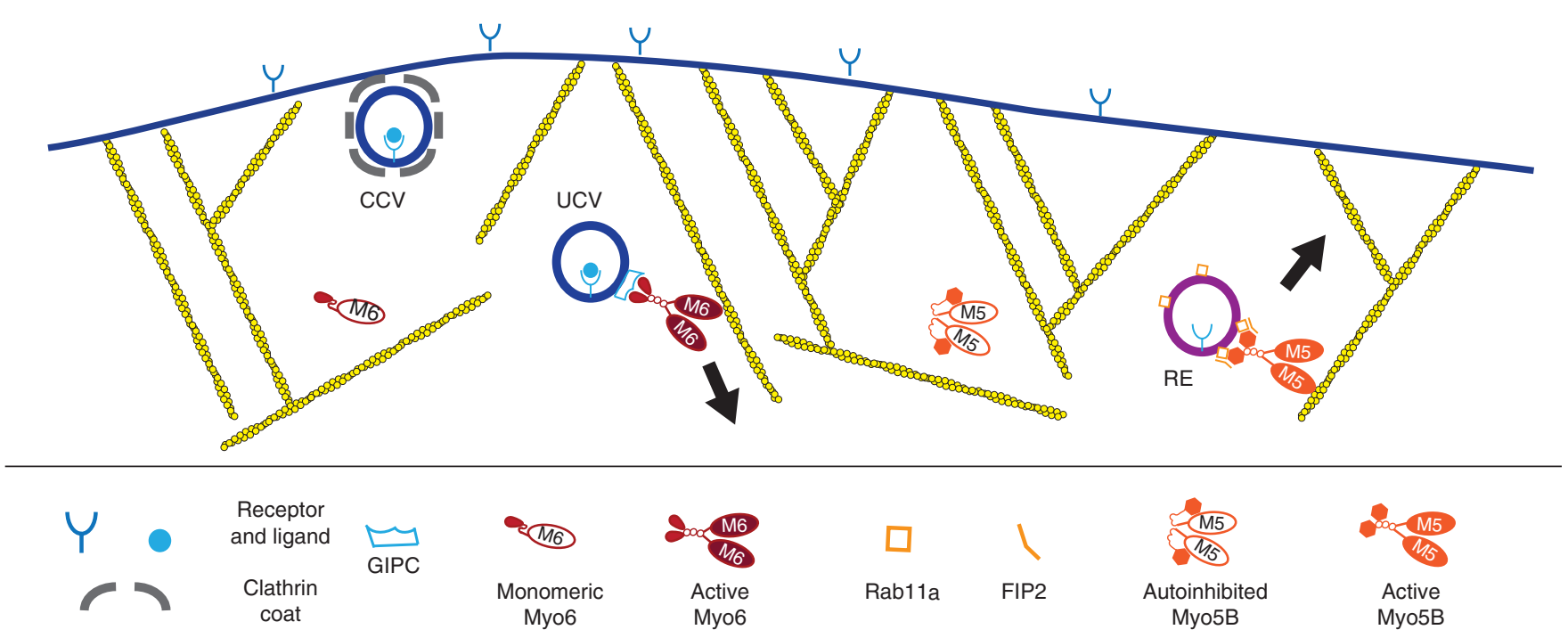

Figure 1. Myosin-based transport of endocytic vesicles. Following the formation of a clathrin-coated vesicle (CCV), it is uncoated (forming an uncoated vesicle, UCV) and myosin VI is recruited through binding to the adaptor GIPC. Recycling endosomes (RE) return membrane receptors and channels (not shown) to the plasma membrane by myosin $\mathrm{Vb}$-based transport. Note that the actin filaments (shown in yellow) are oriented with their barbed ends toward the membrane. 
rather haphazard organization of actin filaments in the cortex.

A variation of this system using a light-sensitive lightoxygen voltage-sensing (LOV) domain targeted to peroxisomes (LOV-PEX) was developed to recruit myosin $\mathrm{Vb}$ fused to a peptide ligand (PDZb1) to this organelle in local regions of cells with illumination with blue light (i.e., an optogenetic approach) (van Bergeijk et al. 2015). This method was applied to dendritic spines of rat hippocampal neurons in primary culture. Spines are actin-rich protrusions that play a role in synaptic plasticity. Stimulation of $N$-methyl-D-aspartate (NMDA) receptors with glycine results in myosin $\mathrm{V}$-dependent internalization of these receptors or targeting of the endoplasmic reticulum (ER) to the spines (Wang et al. 2008; Wagner et al. 2011). Illumination of spines in neurons that express LOV-PEX and myosin $\mathrm{Vb}-\mathrm{PDZb} 1$ resulted in translocation of the peroxisomes into the spine, demonstrating that myosin $\mathrm{Vb}$ can move vesicular cargo along the actin filaments to deliver cargo into these spines.

The availability of systems in which motor activation/ recruitment can be readily manipulated should allow for more detailed studies of myosin-driven movement in other actin-rich regions of the cell. However, it should be noted that this approach does not currently allow for any control over the numbers of each type of motor associated with the organelle, and so it will be necessary to further develop methods to study organelle movements powered by endogenous levels of bound motor.

Myosin VI has several roles in endocytosis, both in transport as well as in tethering organelles to the actin cytoskeleton for fusion or to aid in vesicle release (Bond et al. 2011; Tumbarello et al. 2013). Accordingly, the carboxy-terminal tail region of myosin VI has binding sites for several adapter proteins that are found on endosomes. Alternative splicing determines the presence or absence of long or short inserts (LI and SI, respectively) in the tail of myosin VI and contributes to specifying its binding partners. The myosin VI + LI isoform participates in receptor internalization by promoting the formation of clathrincoated vesicles at the plasma membrane through association with the clathrin adapter Dab2. Myosin VI lacking inserts also participates in receptor uptake through interaction with the adapter GIPC that recruits myosin VI to endocytic vesicles following their uncoating. Myosin VIassociated uncoated vesicles (UCVs) containing the transferrin receptor (TfR) move through the actin-rich peripheral region of ARPE cells at $\sim 35 \mathrm{~nm} / \mathrm{sec}$ (Fig. 1), a velocity significantly lower than that of unloaded myosin VI in vitro (Rock et al. 2001). This could be caused by resistance from structures in the cytoplasm (including the actin network) or inhibition of motor activity. Myosin VI is lost from these vesicles after they fuse with early endosomes marked with EEA1 (Aschenbrenner et al. 2003; Aschenbrenner et al. 2004).

Disruption of myosin VI function significantly reduced movement of UCVs through the actin network, resulting in their accumulation in the cell periphery (Aschenbrenner et al. 2004) and a block in several endocytic processes. For example, slowed transit of UCVs through the cortex in cells deleted of myosin VI causes a decrease in the uptake of the TfR. Delays in the uptake and downstream delivery of receptors to early endosomes via GIPC-positive UCVs can also impact receptor-mediated signaling. Development of the zebrafish arterial system depends on vascular endothelial growth factor (VEGF) signaling in endothelial cells, and so reducing the expression of the fish GIPC (synectin) or myosin VI results in abnormal arterial morphogenesis ( $\mathrm{La}-$ nahan et al. 2010). VEGF binding to endothelial cells results in phosphorylation of the VEGF receptor (VEGF-R) on tyrosine $1175\left(\mathrm{P}-\mathrm{Y}^{1175}\right)$ and promotes internalization through clathrin-mediated endocytosis. Activated VEGF-R is delivered to EEA1-positive early endosomes through myosin VI-dependent transit through the cortex, where it then signals to both the phospholipase $\mathrm{C} \gamma(\mathrm{PLC} \gamma)-$ mitogen-activated protein kinase (MAPK) and phosphoinositide 3-kinase (PI3K)/Akt pathways to promote endothelial development. In the absence of myosin VI, slowed delivery and fusion of UCVs with the early endosome correlates with notably reduced levels of VEGF-R P-Y ${ }^{1175}$, resulting in diminished signaling through these pathways. In the case of both the motility of endocytic UCVs and signaling from the VEGF-R following internalization, the minus end-directed myosin VI takes advantage of the orientation of actin filaments at the plasma membrane to move vesicles into the cell interior.

\section{DISEASES CAUSED BY DEFECTS IN ACTIN-BASED ORGANELLE TRANSPORT}

Loss of organelle transport by myosin $\mathrm{V}$ isoforms is the underlying cause of two rare diseases. Mutations of myosin Va cause Griscelli syndrome, and mutations of myosin $\mathrm{Vb}$ cause microvillus inclusion disease (Van Gele et al. 2009; van der Velde et al. 2013) (see OMIM \#214450 for Griscelli GS1 syndrome and 251850 for MVID [microvillus inclusion disease]).

Griscelli syndrome patients have hypopigmentation (pigment dilution) of the skin and hair and neurological disorders. Patients with Elejalde disease (OMIM \#256710) have symptoms similar to those of Griscelli GS1 patients, and so mutations in myosin Va that await identification might cause the disease (Van Gele et al. 2009). The Griscelli phenotypes are strikingly similar to those of the mouse 
myosin Va dilute mutant (Mercer et al. 1991). The pigmentation defect is due to loss of melanosome transport and transfer of pigment to the keratinocytes of the skin and hair cell shafts. Kinesin transports melanosomes to the periphery of melanocytes, where they are transferred to myosin Va for distribution through the cortex and anchoring on actin just below the plasma membrane ( $\mathrm{Wu}$ and Hammer 2014). A Rab27-melanophilin complex links myosin Va to melanosomes, and loss-of-function mutations in each protein lead to essentially identical pigmentation defects in human and mouse (referred to as Griscelli syndrome GS2 and GS3; ashen and leaden) (Van Gele et al. 2009). The neurological disorder associated with mutations in myosin $\mathrm{Va}$ is consistent with the finding that ER is not transported into the dendritic spines of hippocampal neurons in the dilute mouse (Takagishi et al. 1996; Wagner et al. 2011).

The mutations in MYO5B that cause microvillus inclusion disease disrupt the microvilli on the apical surface of intestinal epithelial cells and result in a devastating loss of intestinal absorption (Cutz et al. 1989; Ruemmele et al. 2006; van der Velde et al. 2013). The diminished absorptive surface area acutely impacts nutrient absorption, resulting in a high incidence of death of newborns. Intestinal epithelial cells in patients have large inclusions filled with microvillar structures and accumulate enzymes normally found in the brush border in the cytoplasm. The loss of myosin $\mathrm{Vb}$ function causes the disease by disrupting the transport of recycling endosomes through the actin cortex to the surface of cells, where they fuse with the plasma membrane. These cells depend on recycling internalized receptors and channels back to the plasma membrane for their absorptive and uptake activities. The phenotypes of mice with mutations of their Myo5b gene resemble those of patients with microvillus inclusion disease (Cartón-García et al. 2015; Schneeberger et al. 2015). These powerful models can be used to provide important insights into how loss of myosin $\mathrm{Vb}$ causes such serious dysfunction of the intestinal epithelium and will potentially aid in devising therapeutic strategies for restoring function.

\section{RNA TRAFFICKING}

A subset of messenger RNAs (mRNAs) is packaged into RNPs for transport and localization to specific regions of a cell, such as the leading edge of a migrating cell, that require timely local control over protein production. The majority of RNP transport in metazoan cells occurs by means of microtubules; however, once these RNPs reach their destination, they can be moved locally along actin filaments by myosin $\mathrm{V}$ family members. In contrast, RNPs move exclusively along actin filaments in yeast, and so studies of RNA trafficking in yeast have provided key insights into the basis of their myosin-dependent transport.

A select set of mRNAs is targeted to the bud of a growing daughter yeast cell. These RNAs can either be packaged into an RNP or associated with cortical endoplasmic reticulum (cER), and the yeast myosin V-Myo4p-is essential for their transport into the bud (Estrada et al. 2003; Shepard et al. 2003; Aronov et al. 2007). In the nucleus, the adaptor protein She2p binds to the mRNA zip code that contains sequences for targeting the mRNA. On export from the nucleus, this RNP complex binds to a complex of the She3p adaptor protein and Myo4p. Depending on the zip code sequence in the RNA, the RNP-motor complex can either bind to a receptor on the cER or remain in the cytoplasm (Singer-Krüger and Jansen 2014). Myo4p is a monomeric, nonprocessive myosin that is unable to move continuously on actin filaments by itself (Reck-Peterson et al. 2001). However, binding to the She $2 p-S h e 3 p$ complex assembles it into a dimeric transport complex that is able to move processively. Reconstitution of this complex in vitro showed that the dimeric adaptor protein She3p binds two Myo4p motors and a She2p tetramer that, in turn, binds to an ASH1 mRNA (Heym et al. 2013; Sladewski et al. 2013). The She2p binds directly to the zip code sequence, allowing for more motors to be recruited to the complex with increasing numbers of zip code sequences. The complex has in vitro run lengths of $1-2 \mu \mathrm{m}$ and moves at velocities comparable to those in vivo, or faster (0.6$2 \mu \mathrm{m} / \mathrm{sec}$ ) (Bertrand et al. 1998). RNA binding might be crucial for the optimal movement of this complex, especially at physiological ionic strengths, but this remains to be firmly established (Heym et al. 2013; Sladewski et al. 2013). Thus, as is true for many of the transport myosins, such as myosin VI and myosin VIIA, cargo binding is the key event that activates the motor for transport.

The exact role of myosins in the transport of RNAs in multicellular organisms is less clear. The Drosophila oocyte provides an example of where the final targeting or localization of an RNP depends on actin and myosin $\mathrm{V}$. In this system, myosin $\mathrm{V}$ (didum) is required for germline specification. The fly myosin $\mathrm{V}$ is found in a complex with the RNA-binding protein Staufen and is required for the localization of oskar RNA to the posterior pole (Krauss et al. 2009).

Similarly, myosin V has a role in targeting RNA to the dendritic spines of mouse hippocampal neurons that have a role in memory and learning. Specific localization of mRNAs plays a role in neuronal plasticity by allowing rapid synthesis of proteins following the stimulation of glutamate receptors with the agonist dihydroxyphenylglycine (DHPG). Mouse myosin Va forms a complex with TLS, an RNA-binding protein in RNPs, and the associated 
mRNA for the kelch family protein Nd1-L, which stabilizes actin filaments (Yoshimura et al. 2006). Myosin Va and TLS colocalize at dendritic spines. Loss of myosin Va function in dilute-lethal mutant mice results in displacement of TLS from spines and loss of actin-dependent transport of the RNP into the spine following DHPG stimulation (Yoshimura et al. 2006).

Loss of myosin Va from human HeLa cells or fibroblasts results in perinuclear accumulation of RNAs or RNPs (Salerno et al. 2008; Lindsay and McCaffrey 2014). This is consistent with myosin Va playing a role in the distribution of RNPs throughout the cell by movement along local actin networks. Together, these findings suggest that myosin $\mathrm{V}$ transports RNPs in both yeast and in multicellular organisms, consistent with this being a fundamentally conserved role for this ancient family of myosins.

\section{MOVEMENT ALONG ACTIN BUNDLES}

A variety of cell types makes specialized membrane projections supported by parallel bundles of actin filaments (see Svitkina 2016). These include filopodia, stereocilia, and microvilli. The uniform orientation of the actin filaments, with the barbed end toward the plasma membrane, creates a superhighway for myosins to deliver cargo either to the tips or the base of these structures. Several different myosins have been implicated in the generation and/or organization of these structures and are proposed to transport components, such as adhesion receptors or regulators of actin polymerization, along the length of the actin core to the tip.

Formation of filopodia requires the function of a myosin-myosin $\mathrm{X}$ in mammalian cells and the functionally related amoeboid myosin VII in Dictyostelium (Tuxworth et al. 2001; Bohil et al. 2006). Growth of filopodia depends on two actin-binding proteins, VASP and formins (reviewed by Pollard 2016). VASP facilitates the addition of actin monomers to growing filament ends, prevents capping of the filaments, and bundles actin filaments. Formins nucleate and stimulate elongation while associating processively with actin filament barbed ends (Faix et al. 2009). Myosin X and VASP move together along the length of filopodia toward the tip at a rate of $\sim 600 \mathrm{~nm} / \mathrm{sec}$, similar to the rate that myosin $\mathrm{X}$ dimers move on actin filaments in vitro (Tokuo and Ikebe 2004; Kerber et al. 2009). Myosin $\mathrm{X}$ transport has been proposed to contribute to the extension of filopodia by delivering VASP to the tip to promote growth of actin filaments (Kerber and Cheney 2011).

Filopodia are important for mediating the interaction between cells and their environment. The carboxy-terminal FERM domain of myosin $\mathrm{X}$ interacts with the cytoplasmic tails of several different types of receptors, including the cytoplasmic tail of the $\beta 1$-integrin adhesion receptor. As the two proteins colocalize in punctae along the length of filopodia, myosin X might transport the adhesion receptor to the filopodial tip (Zhang et al. 2004). Observations of cells expressing mutant myosin $\mathrm{X}$, which does not bind the $\beta 1$-integrin tail, show that this myosin is not required for the adhesion receptor to enter filopodia but has a role in concentrating and anchoring the receptors at the tip, where they can serve as the first point of contact between the cell and the extracellular matrix (Arjonen et al. 2014). Furthermore, the tips in the cells with reduced Myo10 levels appear to fail to be stabilized by substrate contact during growth, resulting in the formation of short filopodia (Zhang et al. 2004; Watanabe et al. 2010).

Myosin X has also been implicated in mediating receptor signaling. The netrin receptor DCC ("deleted in colorectal cancer") has crucial roles in axon guidance, and it has been shown that these receptors require Myo10 for cell signaling (Zhu et al. 2007). Myosin X and DCC are colocalized at filopodial tips, and netrin stimulates the formation of filopodia by activation of VASP (Menon et al. 2015) Similar to $\beta 1$-integrin, myosin $\mathrm{X}$ interacts with the cytoplasmic tail of DCC, and loss of filopodia due to a reduction in myosin $\mathrm{X}$ expression results in reduced neurite outgrowth in cortical explants and embryos. These findings are consistent with filopodial-mediated signaling through netrin having an important role in neuronal pathfinding. Other work shows that myosin X participates in cellular responses to the growth factor bone morphogenetic protein (BMP). Endothelial cells exposed to BMP increase myosin X expression and filopodia number. The BMP receptor ALK6 moves within filopodia, is present at the tip, and it coprecipitates with ectopically expressed GFP-myosin X. Reducing myosin X expression by RNA silencing abrogates BMP signaling and inhibits endothelial tube formation (Pi et al. 2007), suggesting that myosin X trafficking of ALK6 into filopodia is required for BMP signaling. The details of the myosin X-ALK6 interaction, whether it is direct or indirect and how it is regulated, are not yet known.

These studies reveal the importance of filopodia in cellular signaling and are consistent with the proposal that trafficking of receptors to the filopodia tip is crucial for these responses. However, it has not yet been established whether the primary role of myosin $\mathrm{X}$ is in filopodia formation, receptor trafficking to the tip to mediate signaling responses, or both processes.

The hair cells of the cochlea and utricle are the primary sensory cells essential for hearing and balance. These specialized cells extend long projections, called stereocilia, from their apical regions that mediate the response to a sound wave or change in the body's orientation. Stereocilia 
are organized in rows of increasing height and contain a core of parallel bundles of actin. Their formation and function depend on several different myosins, including myosin VI, myosin VIIA, and myosin XVA. Mutations of genes encoding each of these myosins results in deafness: Myosin VI mutations cause deafness types DFNA22 and DFNB37; myosin VIIA mutations cause Usher syndrome Type 1B, DFNB2, and DFNA11; and myosin XVA mutations cause DFNB3 (Dror and Avraham 2009). It has been technically challenging to study the functions of stereocilia myosins given the difficulties inherent in working with cochlear tissue explants embedded in bone. The general similarity between filopodia, which are also made of parallel bundles of actin, and stereocilia has greatly facilitated studies of these myosins and provided crucial molecular insights into their roles in stereocilia.

Mice lacking myosin XVA initiate the growth of stereocilia but their growth is significantly stunted (Probst et al. 1998). Myosin XVA is localized to the tips of stereocilia along with the scaffolding protein whirlin and an actin regulator, Eps8 (Belyantseva et al. 2005; Manor et al. 2011). Myosin XVA is a barbed end-directed motor (Bird et al. 2014) with a PDZ-binding domain at the carboxyl terminus of the tail that interacts directly with the PDZ protein whirlin that, in turn, binds Eps8. Myosin XVA also interacts with Eps8 directly. The phenotypes of whirlin, Eps8, and myosin XVA mutants are almost identicallack of any one of these proteins results in short stereocilia. Myosin XVA is required for the localization of both whirlin and Eps8 to the stereocilia tip, whereas its own localization is independent of whirlin and Eps8. Based on these findings, it has been proposed that myosin XVA transports Eps8 to the stereocilia tips to support their elongation (Fig. 2). Indeed, myosin XVA and whirlin expressed in COS7 cells move along filopodia together and colocalize at the tip (Belyantseva et al. 2005). Interestingly, the aminoterminal extension of myosin XVA is crucial for its targeting to distinct rows of stereocilia (Fang et al. 2015). Analysis of myosin XVA function suggests that it selectively transports a crucial actin regulator to the tips of stereocilia to control their differential elongation.

Myosin IIIA is also a stereocilia myosin implicated in trafficking of components to the stereocilia tip (Fig. 2). This myosin is of particular interest as it is a monomeric kinasemyosin hybrid possessing motor activity autoregulated by phosphorylation (Quintero et al. 2010). Myosin IIIA concentrates at the tips of stereocilia in cochlear hair cells and filopodia when expressed in COS7 cells. Targeting of this myosin in filopodia requires the presence of a second actinbinding site at its carboxyl terminus (THDII) (Erickson et al. 2003; Schneider et al. 2006). Similar to myosin XVA, myosin IIIA interacts with an actin regulator-Espin 1 in this case. Overexpression of both proteins results in longer hair cell stereocilia in cochlear explants, and their coexpression promotes filopodia elongation in COS7 cells. The proteins move together along the length of filopodia at a rate of $40 \mathrm{~nm} / \mathrm{sec}$ and accumulate at the tip (Salles et al. 2009; Merritt et al. 2012). The rate of motility in vivo is similar to that reported for in vitro motility, $\sim 100 \mathrm{~nm} / \mathrm{sec}$ (Komaba et al. 2003). Myosin IIIA is a monomer, and so it cannot move processively in the same hand-over-hand mode used by the dimeric transport myosins such as myosin V or myosin VI. However, the motor has a high affinity for actin in the presence of ATP, whereas the THDII actin binding site has a high off-rate. Thus, the combined properties of the two sites would enable an inchworm-type mechanism allowing myosin IIIA to remain bound to actin filaments but also be released from actin and progress toward the tips of stereocilia or filopodia as the motor undergoes a step (Dosé et al. 2007; Merritt et al. 2012). Surprisingly, the auditory hair cells from mice lacking both myosin IIIA and the closely related myosin IIIB have elongated stereocilia with espin1 still present at the tips (Lelli et al. 2016). These findings indicate that the two myosin IIIs work in concert to control stereocilia length, potentially by delivering a cohort of actin regulators to the tip.

An interesting example of potential myosin-based transport along specialized actin structures is found in intestinal epithelial cells. Microvilli are thin projections of the plasma membrane supported by a bundle of actin filaments on the apical surface of these cells. They increase the absorptive surface area of the intestine and are also an effective barrier against the bacteria in the gut. Microvilli are of uniform height and are linked together all along their lengths. Myosin Ia is the major myosin of the intestinal epithelium and it was proposed to provide a stable link between the actin-rich core of the microvillus and the overlying membrane, acting mainly as tether rather than a motor (Tyska et al. 2005). A mouse mutant lacking myosin Ia does not have any overt defects in brush border formation or intestinal function, except accumulation of membrane and bulges at the tips of some microvilli (Tyska et al. 2005). Beautiful in vitro assays revealed that myosin Ia is not a passive membrane tether, but rather it can provide forces at the tip of microvilli required for shedding of membrane vesicles into the lumen of the intestine (Fig. 3) (McConnell et al. 2009). These lumenal vesicles are rich in alkaline phosphatase and are proposed to be essential for dephosphorylating bacterial lipopolysaccharides, thus, limiting bacterial growth and preventing the adhesion of enteropathogenic Escherichia coli (EPEC) to the epithelial cells (Shifrin et al. 2012). The mechanism by which myosin Ia moves promotes the movement of membranes or membrane domains near the tip or possibly along the length 


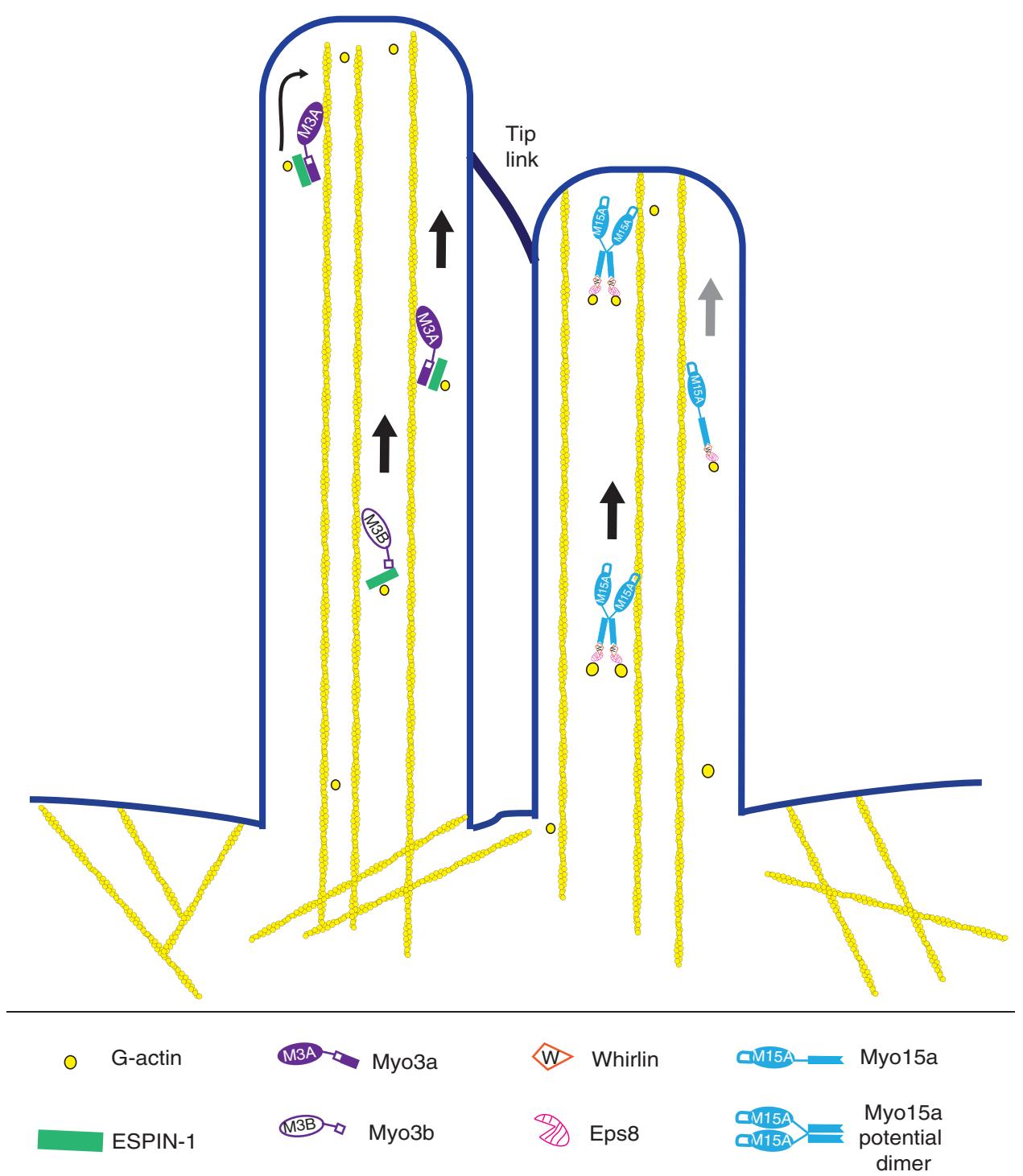

Figure 2. Transport of actin elongation proteins in stereocilia. Two different myosins, myosin IIIA/B and myosin XVA, move up the polarized actin core of the stereocilium (shown in yellow), which is oriented with barbed ends pointed toward the membrane at the tip. Each myosin carries a cargo that includes an adaptor protein(s) (Espin-1 for myosin III, whirlin and Eps8 for myosin XVA) and an actin monomer that is added at the tip. Note that, as it is not known whether myosin XVA is a dimer, it might move as a processive dimer or by facilitated diffusion (gray arrow) if it is monomer.

of the microvillus is not yet clear. It is a monomeric nonprocessive motor, and so it seems likely that several motors must be organized in a cluster and linked to the phosphatase to promote vesicle shedding by an as yet unknown mechanism.

Myosin VI is found in the actin-rich apical regions of both cochlear hair cells and polarized epithelial cells that extend brush borders, such as intestinal epithelial cells and kidney proximal tubule cells. This myosin has a role in the internalization of clathrin-coated vesicles at the base of the apical stereocilia or microvilli but might also play a role in transporting receptors down the length of the microvillus to the base for internalization (Fig. 3). Intestinal epithelial cells of the myosin VI-null mutant mouse have increased apical membrane levels of the cystic fibrosis transmembrane conductance regulator (CFTR) channel, consistent with a defect in endocytic uptake (Ameen and Apodaca 2007). The sodium and phosphate cotransporters, types IIa and IIc, on the brush border are internalized in kidney proximal tubule cells on stimulation with parathyroid hormone, but this process is significantly decreased in the absence of myosin VI (Blaine et al. 2009). Intestinal epithe- 
M.A. Titus

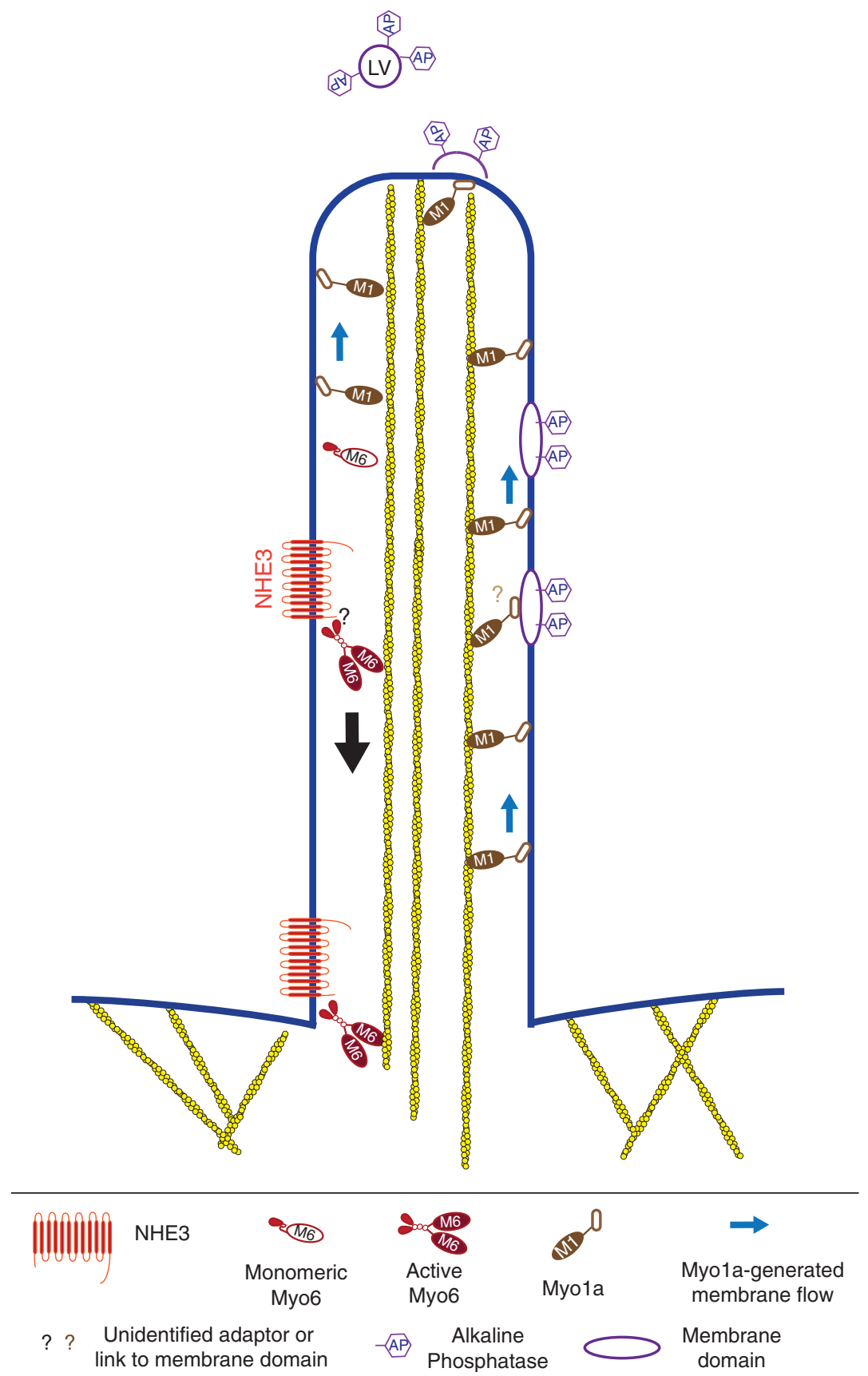

Figure 3. Myosin-based transport in microvilli. The drawing illustrates the tip-to-base movement of the sodiumhydrogen exchanger (NHE3) powered by myosin VI (Myo6). Note that myosin VI is monomeric and that binding to its cargo promotes dimerization. In contrast, myosin Ia (Myola) binds directly to membrane lipids and may directly move components in the opposite direction, from base to tip, or effect changes in membrane tension to promote the shedding of vesicles (LV) enriched for alkaline phosphatase (AP) into the lumen of the gut.

lial cells stimulated with either carbachol or forskolin typically internalize the sodium-hydrogen exchanger NHE3. However, in the absence of myosin VI, the levels of the exchanger are significantly higher than normal in apical surface membranes (Chen et al. 2014) and isolated brush border membranes (Hegan et al. 2012). Examination of the distribution of NHE3 along the length of the microvillus revealed a greater amount of the exchanger in the apicalmost region of the protrusion in these cells (Chen et al. 2014), consistent with myosin VI having a role in the movement of NHE3 from the tip of the microvillus toward the base where internalization would occur. 
The finding that myosin VI is required for efficient uptake of several different epithelial receptors/transporters following stimulation, together with the orientation of the actin bundle within microvilli (pointed ends toward the interior of the cell), supports a role for this motor in moving these proteins within the plane of the brush border membrane to the base, where abundant uptake machinery resides. An outstanding question is how the motor is linked to these integral membrane proteins and how various signals activate the myosin to engage the receptor or transporter for movement down the microvillus and either transfer the transporter to the endocytic machinery or switch myosin VI to having a role in recruiting components of the clathrin-coated vesicle.

\section{LONG-DISTANCE TRANSPORT}

Myosin-based transport typically occurs over relatively short distances in mammalian cells. However, an unusual example of long-range transport has been described in the mouse oocyte (Schuh 2011; Holubcová et al. 2013). During maturation, these cells move their spindle to the cortex, where, following meiotic division, they produce a large oocyte and a small daughter cell called a polar body. Spindle positioning depends on the actin cytoskeleton that is organized into a large network connected by nodes that are separated by $\sim 5 \mu \mathrm{m}$ from each other. Each node includes a vesicle associated with Rab1la and myosin $\mathrm{Vb}$. These vesicles move at $12 \mu \mathrm{m} / \mathrm{min}$ (the speed of myosin $\mathrm{Vb}$ in vitro; Watanabe et al. 2006) for distances of up to $30 \mu \mathrm{m}$ from the cell center to periphery. The vesicles serve as nucleation centers for actin polymerization, as does the plasma membrane, recruiting the actin elongation proteins Spire and formin that promote the elongation of individual actin filaments. Actin filaments growing from the vesicles provide tracks for myosin $\mathrm{Vb}$-dependent movement of the vesicles toward each other, resulting in vesicle fusion. But because the vesicles are connected, myosin $\mathrm{Vb}$ translocation results in movement of the entire network. Ultimately, the network moves toward the plasma membrane, and this is crucial for positioning the spindle that is moved along with it. Loss of myosin $\mathrm{Vb}$ activity inhibits vesicle fusion and network movement, and spindle position at the membrane no longer occurs. This is potentially a widely used mechanism for promoting intracellular vesicle transport as it has recently been shown that myosin Va and Spir are coordinately recruited to Rab 11 vesicle membranes in mammalian cultured cells (Pylypenko et al. 2016). Much remains to be learned about the molecular details of this unusual and intriguing form of myosinbased organelle transport, and it will be of interest to see if this form of organelle motility that is driven by formation of its own network and tracks is indeed seen in other contexts.

\section{CYTOPLASMIC STREAMING IN PLANTS}

One of the first-studied examples of actin-based transport is the cytoplasmic streaming of plant cells. In contrast to animal cells but similar to yeast, plants use actin filaments as their major cytoskeletal highway. Cytoplasmic streaming is observed in a wide range of plant species and cell types, such as leaf cells of Arabidopsis, which move intracellular contents at a rate of $4 \mu \mathrm{m} / \mathrm{sec}$ (Tominaga et al. 2013). The intermodal cells of Characean algae are quite large (up to $10-\mathrm{cm}$ long for a single cell), and they show robust cytoplasmic streaming occurring at a remarkable rate of $60 \mu \mathrm{m} / \mathrm{sec}$. Early elegant experiments by Kamiya and colleagues established that a motive force was generated at regions of the cell close to the plasma membrane, in which cables of uniformly polarized actin filaments reside to support an actomyosin-based mechanism for streaming (Shimmen 2007; Tominaga and Ito 2015). The movement of endoplasmic vesicles along actin filaments generates the motive force for cytoplasmic streaming and appears to be essential for the efficient distribution of organelles throughout the cells. The myosin responsible for streaming is myosin XI (Fig. 4). This myosin is similar in overall domain organization to the more widely expressed myosin $\mathrm{V}$, but it is a distinct class of plant-specific myosin, with myosin XI family members having biochemical and biophysical motor properties that differ from those of myosin $\mathrm{V}$ in several respects (Avisar et al. 2009; Tominaga and Ito 2015). Purified Chara corallina (Cc) myosin XI is indeed a remarkable motor protein-it moves actin filaments in vitro at a speed of $60 \mu \mathrm{m} / \mathrm{sec}$ (Kimura et al. 2003), a speed significantly faster than vertebrate fast skeletal muscle myosin. The tobacco (Nt) myosin XI is also a fast motor-it moves at $7 \mu \mathrm{m} / \mathrm{sec}$ (Tominaga et al. 2003). Although both motors can move actin filaments at high rates of speed, their motor properties differ- $\mathrm{Nt}$ myosin $\mathrm{XI}$ is processive, whereas Cc myosin XI is most likely nonprocessive owing to differences in their biochemical properties. Only a small number of processive myosins would be needed to move an organelle, whereas larger numbers of the nonprocessive motors would be necessary to propel continuous organelle movement.

Plants express multiple class XI myosins-for example, there are 14 in Arabidopsis (Madison and Nebenfuhr 2013), presenting a challenge for studying the role of a given motor owing to redundancy between the different motors. However, studies of mutants in multiple myosin genes or the effects of the overexpression of tails in Arabidopsis and 
M.A. Titus

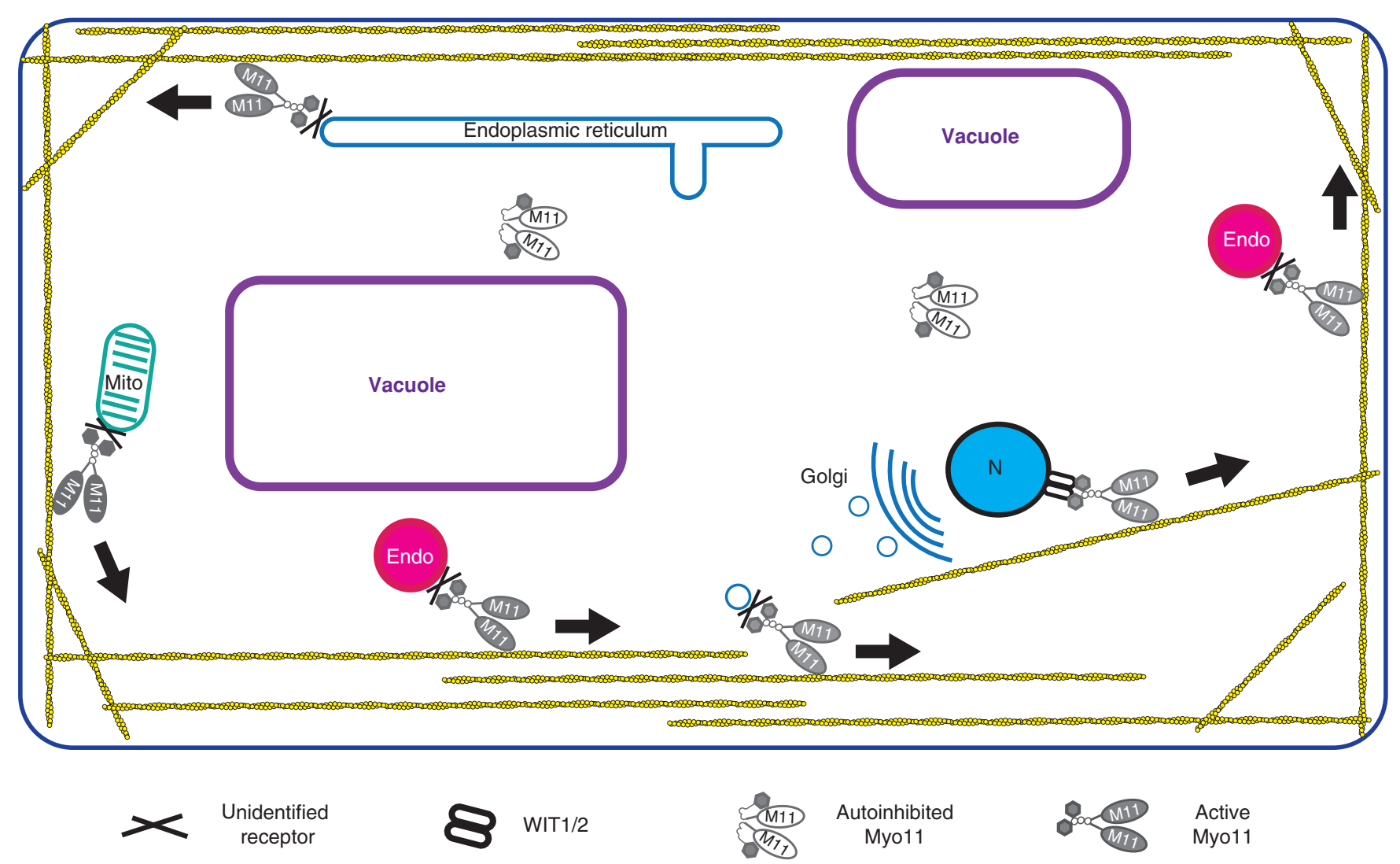

Figure 4. Cytoplasmic streaming and nuclear movement in plant cells. The drawing shows the movements of a variety of organelles, including the nucleus $(\mathrm{N})$, endocytic vesicles (Endo), Golgi, endoplasmic reticulum, and mitochondria (Mito). Note that these are likely to be driven by several different myosin XI isoforms, and a given organelle can be associated with more than one type of myosin XI. The adapter(s) linking myosin XI to each organelle are not known, but the WIT1/2 proteins are known to recruit myosin XI-i to the nuclear membrane in Arabidopsis (Tamura et al. 2013).

RNA interference in the moss Physcomitrella have provided strong support for a role for myosin XI in organelle transport and streaming in these two plant systems (Madison and Nebenfuhr 2013). Several different myosins have been implicated in the transport of Golgi, peroxisomes, mitochondria, and the ER. It appears that disrupting one myosin can impact the motility of several different organelles, possibly owing to the presence of more than one type of myosin XI on a given organelle. Alternatively, the transport could be indirect, and the rapid movement of some cargo along actin tracks can drive the overall movement of many other organelles. Myosin XI family members have also been implicated in actin organization, and so loss of one could lead to defects in organization of actin tracks (Cai et al. 2014). In contrast, Arabidopsis myosin XI-I has a specific role in movement of the nucleus and plays a role in linking the nucleus to the actin cytoskeleton. Loss of this myosin results in alterations in shape, dark-induced movements, and positioning of the nucleus (Tamura et al. 2013). Working out the relationship between specific plant myosins and organelle motility will be challenging, given the large number of myosin genes and the range of cellular contexts and developmental stages that they operate in.

Cytoplasmic streaming has long been suggested to play a crucial role in overall plant growth (Prokhnevsky et al. 2008; Ojangu et al. 2012), but only recently has support for this proposal been obtained. A clever experiment using chimeric myosins was used to investigate the link between streaming velocity and growth in Arabidopsis. The motor domain of At myosin XI-2 was replaced by the much faster Cc myosin XI motor or a significantly slower human myo$\sin \mathrm{Vb}$ motor and the chimeric myosins expressed in the Arabidopsis myo11-2 null mutant (Tominaga et al. 2013). Amazingly, plants expressing the Cc myosin XIAt myosin XI-2 chimera showed a threefold faster rate of streaming, and the overall size of the plant and leaf tissue was increased significantly compared with controls. In contrast, the plants expressing the $\mathrm{Hs}$ myosin $\mathrm{Vb}-\mathrm{At}$ myosin XI-2 chimera showed little or no streaming, and the plants were smaller. These findings are quite consistent with 
a model whereby rapid myosin XI-based motility of organelles plays a crucial role in distributing these throughout the plant cell to favor optimal growth. There remain many questions about how this movement of organelles has such a dramatic effect on plant size, but it now seems clear that myosin XI-based motility plays a critical role in plant growth by driving the cytoplasmic streaming of organelles.

\section{CONCLUSION}

Myosins transport a remarkable variety of intracellular cargoes. The underlying biochemical and biophysical properties of transport motors are now well understood and much is also known about how the myosin is targeted to a specific cargo. The future challenge is to gain an understanding of how motor recruitment and activity are controlled at the local level and how motors are organized on the cargo itself.

\section{ACKNOWLEDGMENTS}

I thank Ashley Arthur and Karl Petersen for helpful comments and extend apologies to my colleagues in the field for not citing all of the relevant papers owing to space limitations. The Titus lab is supported by a grant from the $\mathrm{Na}$ tional Science Foundation (MCB-1244235).

\section{REFERENCES}

Ameen N, Apodaca G. 2007. Defective CFTR apical endocytosis and enterocyte brush border in myosin VI-deficient mice. Traffic 8: $998-$ 1006.

Arjonen A, Kaukonen R, Mattila E, Rouhi P, Högnäs G, Sihto H, Miller BW, Morton JP, Bucher E, Taimen P, et al. 2014. Mutant p53-associated myosin-X upregulation promotes breast cancer invasion and metastasis. J Clin Invest 124: 1069-1082.

Aronov S, Gelin-Licht R, Zipor G, Haim L, Safran E, Gerst JE. 2007. mRNAs encoding polarity and exocytosis factors are cotransported with the cortical endoplasmic reticulum to the incipient bud in Saccharomyces cerevisiae. Mol Cell Biol 27: 3441-3455.

Aschenbrenner L, Lee TT, Hasson T. 2003. Myo6 facilitates the translocation of endocytic vesicles from cell peripheries. Mol Biol Cell 14: $2728-2743$.

Aschenbrenner L, Naccache SN, Hasson T. 2004. Uncoated vesicles require the unconventional myosin, Myo6, for rapid transport through actin barriers. Mol Biol Cell 15: 2253-2263.

Avisar D, Abu-Abied M, Belausov E, Sadot E, Hawes C, Sparkes IA. 2009. A comparative study on the involvement of 17 Arabidopsis myosin family members on the motility of Golgi and other organelles. Plant Physiol 150: 700-709.

* Barlan K, Gelfand VI. 2016. Microtubule-based transport and the distribution, tethering and organization of organelles 2016. Cold Spring Harb Perspect Biol doi: 101101/cshperspect.a025817.

Belyantseva IA, Boger ET, Naz S, Frolenkov GI, Sellers JR, Ahmed ZM, Griffith AJ, Friedman TB. 2005. Myosin-XVa is required for tip localization of whirlin and differential elongation of hair-cell stereocilia. Nat Cell Biol 7: 148-156.

Bertrand E, Chartrand P, Schaefer M, Shenoy SM, Singer RH, Long RM. 1998. Localization of ASH1 mRNA particles in living yeast. Mol Cell 2: $437-445$.
Bird JE, Takagi Y, Billington N, Strub MP, Sellers JR, Friedman TB. 2014. Chaperone-enhanced purification of unconventional myosin 15, a molecular motor specialized for stereocilia protein trafficking. Proc Natl Acad Sci 111: 12390-12395.

Blaine J, Okamura K, Arnal H, Breusegem S, Caldas Y, Millard A, Barry N, Levi M. 2009. PTH-induced internalization of apical membrane NaPi2a: Role of actin and myosin VI. Am J Physiol, Cell Physiol 297: C1339-C1346.

Bohil AB, Robertson BW, Cheney RE. 2006. Myosin-X is a molecular motor that functions in filopodia formation. Proc Natl Acad Sci 103: 12411-12416.

Bond LM, Brandstaetter H, Sellers JR, Kendrick-Jones J, Buss F. 2011. Myosin motor proteins are involved in the final stages of the secretory pathways. Biochem SocTrans 39: 1115-1119.

Cai C, Henty-Ridilla JL, Szymanski DB, Staiger CJ. 2014. Arabidopsis Myosin XI: A motor rules the tracks. Plant Physiol 166: 1359-1370.

Cartón-García F, Overeem AW, Nieto R, Bazzocco S, Dopeso H, Macaya I, Bilic J, Landolfi S, Hernandez-Losa J, Schwartz S, et al. 2015. Myo5b knockout mice as a model of microvillus inclusion disease. Sci Rep 5: 12312.

Chen T, Hubbard A, Murtazina R, Price J, Yang J, Cha B, Sarker R, Donowitz M. 2014. Myosin VI mediates the movement of NHE3 down the microvillus in intestinal epithelial cells. J Cell Sci 127: $3535-3545$.

Cheney RE, O'Shea MK, Heuser JE, Coelho MV, Wolenski JA, Espreafico EM, Forscher P, Larson RE, Mooseker MS. 1993. Brain myosin-V is a two-headed unconventional myosin with motor activity. Cell 75: 1323.

Cutz E, Rhoads JM, Drumm B, Sherman PM, Durie PR, Forstner GG. 1989. Microvillus inclusion disease: An inherited defect of brush-border assembly and differentiation. N Engl J Med 320: 646-651.

Donovan KW, Bretscher A. 2015. Head-to-tail regulation is critical for the in vivo function of myosin V. J Cell Biol 209: 359-365.

Dosé AC, Ananthanarayanan S, Moore JE, Burnside BM, Yengo C. 2007. Kinetic mechanism of human myosin IIIA. J Biol Chem 282: 216-231.

Dror AA, Avraham KB. 2009. Hearing loss: Mechanisms revealed by genetics and cell biology. Annu Rev Genet 43: 411-437.

Erickson FL, Corsa AC, Dosé A, Burnside B. 2003. Localization of a class III myosin to filopodia tips in transfected HeLa cells. Mol Biol Cell 14: 4173-4180.

Estrada P, Kim J, Coleman J, Walker L, Dunn B, Takizawa P, Novick P, Ferro-Novick S. 2003. Myo4p and She3p are required for cortical ER inheritance in Saccharomyces cerevisiae. J Cell Biol 163: 1255-1266.

Faix J, Breitsprecher D, Stradal TE, Rottner K. 2009. Filopodia: Complex models for simple rods. Int J Biochem Cell Biol 41: 1656-1664.

Fang Q, Indzhykulian AA, Mustapha M, Riordan GP, Dolan DF, Friedman TB, Belyantseva IA, Frolenkov GI, Camper SA, Bird JE. 2015. The $133-\mathrm{kDa} \mathrm{N}$-terminal domain enables myosin 15 to maintain mechanotransducing stereocilia and is essential for hearing. Elife 4: e08627.

Greenberg MJ, Lin T, Goldman YE, Shuman H, Ostap EM. 2012. Myosin IC generates power over a range of loads via a new tension-sensing mechanism. Proc Natl Acad Sci 109: E2433-E2440.

Hammer JA III, Sellers JR. 2011. Walking to work: Roles for class V myosins as cargo transporters. Nat Rev Mol Cell Biol 13: 13-26.

Hegan PS, Giral H, Levi M, Mooseker MS. 2012. Myosin VI is required for maintenance of brush border structure, composition, and membrane trafficking functions in the intestinal epithelial cell. Cytoskeleton (Hoboken) 69: 235-251.

Heym RG, Zimmermann D, Edelmann FT, Israel L, Ökten Z, Kovar DR, Niessing D. 2013. In vitro reconstitution of an mRNA-transport complex reveals mechanisms of assembly and motor activation. J Cell Biol 203: $971-984$.

Holubcová Z, Howard G, Schuh M. 2013. Vesicles modulate an actin network for asymmetric spindle positioning. Nat Cell Biol 15: 937947.

Hutagalung AH, Novick PJ. 2011. Role of Rab GTPases in membrane traffic and cell physiology. Physiol Rev 91: 119-149. 
Jean S, Kiger AA. 2012. Coordination between RAB GTPase and phosphoinositide regulation and functions. Nat Rev Mol Cell Biol 13: 463470.

Kapitein LC, van Bergeijk P, Lipka J, Keijzer N, Wulf PS, Katrukha EA, Akhmanova A, Hoogenraad CC. 2013. Myosin-V opposes microtubule-based cargo transport and drives directional motility on cortical actin. Curr Biol 23: 828-834.

Kee AJ, Yang L, Lucas CA, Greenberg MJ, Martel N, Leong GM, Hughes WE, Cooney GJ, James DE, Ostap EM, et al. 2015. An actin filament population defined by the tropomyosin Tpm3.1 regulates glucose uptake. Traffic 16: 691-711.

Kerber ML, Cheney RE. 2011. Myosin-X: A MyTH-FERM myosin at the tips of filopodia. J Cell Sci 124: 3733-3741.

Kerber ML, Jacobs DT, Campagnola L, Dunn BD, Yin T, Sousa AD, Quintero OA, Cheney RE. 2009. A novel form of motility in filopodia revealed by imaging Myosin-X at the single-molecule level. Curr Biol 19: 967-973.

Kimura Y, Toyoshima N, Hirakawa N, Okamoto K, Ishijima A. 2003. A kinetic mechanism for the fast movement of Chara myosin. J Mol Biol 328: 939-950.

Komaba S, Inoue A, Maruta S, Hosoya H, Ikebe M. 2003. Determination of human myosin III as a motor protein having protein kinase activity. J Biol Chem 278: 21352-21360.

Krauss J, Lopez de Quinto S, Nusslein-Volhard C, Ephrussi A. 2009. Myosin-V regulates oskar mRNA localization in the Drosophila oocyte. Curr Biol 19: 1058-1063.

Krementsov DN, Krementsova EB, Trybus KM. 2004. Myosin V: Regulation by calcium, calmodulin, and the tail domain. J Cell Biol 164: $877-886$.

Laakso JM, Lewis JH, Shuman H, Ostap EM. 2008. Myosin I can act as a molecular force sensor. Science 321: 133-136.

Lanahan AA, Hermans K, Claes F, Kerley-Hamilton JS, Zhuang ZW, Giordano FJ, Carmeliet P, Simons M. 2010. VEGF Receptor 2 endocytic trafficking regulates arterial morphogenesis. Dev Cell 18: 713724.

Lelli A, Michel V, Boutet de Monvel J, Cortese M, Bosch-Grau M, Aghaie A, Perfettini I., Dupont T, Avan P, El-Amraoui A, et al. 2016. Class III myosins shape the auditory hair bundles by limiting microvilli and stereocilia growth. J Cell Biol 212: 231-244.

Li D, Mabuchi K, Ikebe R, Ikebe M. 2004. $\mathrm{Ca}^{2+}$-induced activation of ATPase activity by myosin Va is accompanied with a large conformational change. Biochem Biophys Res Commun 315: 538-545.

Li XD, Ikebe R, Ikebe M. 2005. Activation of myosin Va function by melanophilin, a specific docking partner of myosin Va. J Biol Chem 280: $17815-17822$.

Li XD, Jung HS, Wang Q, Ikebe R, Craig R, Ikebe M. 2008. The globular tail domain puts on the brake to stop the ATPase cycle of myosin Va. Proc Natl Acad Sci 105: 1140-1145.

Lindsay AJ, McCaffrey MW. 2014. Myosin Va is required for the transport of Fragile X Mental Retardation Protein (FMRP) granules. Biol Cell 106: $57-71$.

Liu J, Taylor DW, Krementsova EB, Trybus KM, Taylor KA. 2006. Threedimensional structure of the myosin $\mathrm{V}$ inhibited state by cryoelectron tomography. Nature 442: 208-211.

Madison SL, Nebenfuhr A. 2013. Understanding myosin functions in plants: Are we there yet? Curr Opin Plant Biol 16: 710-717.

Manor U, Disanza A, Grati M, Andrade L, Lin H, Di Fiore PP, Scita G, Kachar B. 2011. Regulation of stereocilia length by Myosin XVa and Whirlin depends on the actin-regulatory protein Eps8. Curr Biol 21: $167-172$.

McConnell RE, Higginbotham JN, Shifrin DAJ, Tabb DL, Coffey RJ, Tyska MJ. 2009. The enterocyte microvillus is a vesicle-generating organelle. J Cell Biol 185: 1285-1298.

Menon S, Boyer NP, Winkle CC, McClain LM, Hanlin CC, Pandey D, Rothenfußer S, Taylor AM, Gupton SL. 2015. The E3 ubiquitin ligase TRIM9 is a filopodia off switch required for netrin-dependent axon guidance. Dev Cell 35: 698-712.
Mercer JA, Seperack PK, Strobel MC, Copeland NG, Jenkins NA. 1991. Novel myosin heavy chain encoded by murine dilute coat colour locus. Nature 349: 709-713.

Merritt RC, Manor U, Salles FT, Grati M, Dosé AC, Unrath WC, Quintero OA, Yengo CM, Kachar B. 2012. Myosin IIIB uses an actin-binding motif in its espin-1 cargo to reach the tips of actin protrusions. Curr Biol 22: 320-325.

Nascimento AF, Trindade DM, Tonoli CC, de Giuseppe PO, Assis LH, Honorato RV, de Oliveira PS, Mahajan P, Burgess-Brown NA, von Delft F, et al. 2013. Structural insights into functional overlapping and differentiation among myosin V motors. J Biol Chem 288: 34131-34145.

Ojangu EL, Tanner K, Pata P, Jarve K, Holweg CL, Truve E, Paves H. 2012. Myosins XI-K, XI-1, and XI-2 are required for development of pavement cells, trichomes, and stigmatic papillae in Arabidopsis. BMC Plant Biol 12: 81.

Phichith D, Travaglia M, Yang Z, Liu X, Zong AB, Safer D, Sweeney HL. 2009. Cargo binding induces dimerization of myosin VI. Proc Natl Acad Sci 106: 17320-17324.

Pi X, Ren R, Kelley R, Zhang C, Moser M, Bohil AB, Divito M, Cheney RE, Patterson C. 2007. Sequential roles for myosin-X in BMP6-dependent filopodial extension, migration, and activation of BMP receptors. J Cell Biol 179: 1569-1582.

* Pollard TD. 2016. Actin and actin-binding proteins. Cold Spring Harb Perspect Biol doi: 101101/cshperspect.a018226.

Probst FJ, Fridell RA, Raphael Y, Saunders TL, Wang A, Liang Y, Morell RJ, Touchman JW, Lyons RH, Noben-Trauth K, et al. 1998. Correction of deafness in shaker-2 mice by an unconventional myosin in a BAC transgene. Science 280: 1444-1447.

Prokhnevsky AI, Peremyslov VV, Dolja VV. 2008. Overlapping functions of the four class XI myosins in Arabidopsis growth, root hair elongation, and organelle motility. Proc Natl Acad Sci 105: 19744-19749.

Pylypenko O, Attanda W, Gauquelin C, Lahmani M, Coulibaly D, Baron B, Hoos S, Titus MA, England P, Houdusse AM. 2013. Structural basis of myosin V Rab GTPase-dependent cargo recognition. Proc Natl Acad Sci 110: 20443-20448.

Pylypenko O, Welz T, Tittel J, Kollmar M, Chardon F, Malherbe G, Weiss S, Michel CIL, Samol-Wolf A, Grasskamp AT, et al. 2016. Coordinated recruitment of Spir actin nucleators and myosin V motors to Rab11 vesicle membranes. eLife 5: e17523.

Quintero OA, Moore JE, Unrath WC, Manor U, Salles FT, Grati M, Kachar B, Yengo CM. 2010. Intermolecular autophosphorylation regulates myosin IIIA activity and localization in parallel actin bundles. $J$ Biol Chem 285: 35770-35782.

Reck-Peterson SL, Tyska MJ, Novick PJ, Mooseker MS. 2001. The yeast class $\mathrm{V}$ myosins, Myo2p and Myo4p, are nonprocessive actin-based motors. J Cell Biol 153: 1121-1126.

Rock RS, Rice SE, Wells AL, Purcell TJ, Spudich JA, Sweeney HL. 2001. Myosin VI is a processive motor with a large step size. Proc Natl Acad Sci 98: $13655-13659$.

Rodionov VI, Hope AJ, Svitkina TM, Borisy GG. 1998. Functional coordination of microtubule-based and actin-based motility in melanophores. Curr Biol 8: 165-168.

Rogers SL, Gelfand VI. 1998. Myosin cooperates with microtubule motors during organelle transport in melanophores. Curr Biol 8: 161163.

Roland JT, Bryant DM, Datta A, Itzen A, Mostov KE, Goldenring JR. 2011. Rab GTPase-Myo5B complexes control membrane recycling and epithelial polarization. Proc Natl Acad Sci 108: 2789-2794.

Ruemmele FM, Schmitz J, Goulet O. 2006. Microvillous inclusion disease (microvillous atrophy). Orphanet J Rare Dis 1: 22.

Sakai T, Umeki N, Ikebe R, Ikebe M. 2011. Cargo binding activates myosin VIIA motor function in cells. Proc Natl Acad Sci 108: 7028 7033.

Salerno VP, Calliari A, Provance DWJ, Sotelo-Silveira JR, Sotelo JR, Mercer JA. 2008. Myosin-Va mediates RNA distribution in primary fibroblasts from multiple organs. Cell Motil Cytoskeleton 65: 422-433. 
Salles FT, Merritt RCJ, Manor U, Dougherty GW, Sousa AD, Moore JE, Yengo CM, Dosé AC, Kachar B. 2009. Myosin IIIa boosts elongation of stereocilia by transporting espin 1 to the plus ends of actin filaments. Nat Cell Biol 11: 443-450.

Schafer JC, Baetz NW, Lapierre LA, McRae RE, Roland JT, Goldenring JR. 2014. Rab11-FIP2 interaction with MYO5B regulates movement of Rab1la-containing recycling vesicles. Traffic 15: 292-308.

Schneeberger K, Vogel GF, Teunissen H, van Ommen DD, Begthel H, El Bouazzaoui L, van Vugt AH, Beekman JM, Klumperman J, Müller T, et al. 2015. An inducible mouse model for microvillus inclusion disease reveals a role for myosin $\mathrm{Vb}$ in apical and basolateral trafficking. Proc Natl Acad Sci 112: 12408-12413.

Schneider ME, Dose AC, Salles FT, Chang W, Erickson FL, Burnside B, Kachar B. 2006. A new compartment at stereocilia tips defined by spatial and temporal patterns of myosin IIIa expression. J Neurosci 26: $10243-10252$.

Schroeder HW, Hendricks AG, Ikeda K, Shuman H, Rodionov V, Ikebe M, Goldman YE, Holzbaur EL. 2012. Force-dependent detachment of Kinesin-2 biases track switching at cytoskeletal filament intersections. Biophys J 103: 48-58.

Schuh M. 2011. An actin-dependent mechanism for long-range vesicle transport. Nat Cell Biol 13: 1431-1436.

Schuster M, Treitschke S, Kilaru S, Molloy J, Harmer NJ, Steinberg G. 2011. Myosin-5, kinesin-1 and myosin-17 cooperate in secretion of fungal chitin synthase. EMBO J 31: 214-227.

Sckolnick M, Krementsova EB, Warshaw DM, Trybus KM. 2013. More than just a cargo adapter, melanophilin prolongs and slows processive runs of myosin Va. J Biol Chem 288: 29313-29322.

Shepard KA, Gerber AP, Jambhekar A, Takizawa PA, Brown PO, Herschlag D, DeRisi JL, Vale RD. 2003. Widespread cytoplasmic mRNA transport in yeast: Identification of 22 bud-localized transcripts using DNA microarray analysis. Proc Natl Acad Sci 100: 11429-11434.

Shifrin DA, McConnell RE, Nambiar R, Higginbotham JN, Coffey RJ, Tyska MJ. 2012. Enterocyte microvillus-derived vesicles detoxify bacterial products and regulate epithelial-microbial interactions. Curr Biol 22: 627-631.

Shimmen T. 2007. The sliding theory of cytoplasmic streaming: Fifty years of progress. J Plant Res 120: 31-43.

Singer-Krüger B, Jansen RP. 2014. Here, there, everywhere. mRNA localization in budding yeast. RNA Biol 11: 1031-1039.

Sladewski TE, Bookwalter CS, Hong MS, Trybus KM. 2013. Single-molecule reconstitution of mRNA transport by a class $\mathrm{V}$ myosin. Nat Struct Mol Biol 20: 952-957.

* Svitkina T. 2016. Actin cytoskeleton and actin-based motility. Cold Spring Harb Perspect Biol doi: 101101/cshperspect.a018267.

* Sweeney HL, Holzbaur ELF. 2016. Motor proteins. Cold Spring Harb Perspect Biol doi: 101101/cshperspect.a021931.

Takagishi Y, Oda S, Hayasaka S, Dekker-Ohno K, Shikata T, Inouye M, Yamamura H. 1996. The dilute-lethal $\left(d^{l}\right)$ gene attacks a Ca ${ }^{2+}$ store in the dendritic spine of Purkinje cells in mice. Neurosci Lett 215: 169172 .

Tamura K, Iwabuchi K, Fukao Y, Kondo M, Okamoto K, Ueda H, Nishimura M, Hara-Nishimura I. 2013. Myosin XI-i links the nuclear membrane to the cytoskeleton to control nuclear movement and shape in Arabidopsis. Curr Biol 23: 1776-1781.

Thirumurugan K, Sakamoto T, Hammer JA, Sellers JR, Knight PJ. 2006. The cargo-binding domain regulates structure and activity of myosin 5. Nature 442: 212-215.

Tokuo H, Ikebe M. 2004. Myosin X transports Mena/VASP to the tip of filopodia. Biochem Biophys Res Commun 319: 214-220.

Tominaga M, Ito K. 2015. The molecular mechanism and physiological role of cytoplasmic streaming. Curr Opin Plant Biol 27: 104-110.

Tominaga M, Kojima H, Yokota E, Orii H, Nakamori R, Katayama E, Anson M, Shimmen T, Oiwa K. 2003. Higher plant myosin XI moves processively on actin with $35 \mathrm{~nm}$ steps at high velocity. EMBO J 22: $1263-1272$.
Tominaga M, Kimura A, Yokota E, Haraguchi T, Shimmen T, Yamamoto K, Nakano A, Ito K. 2013. Cytoplasmic streaming velocity as a plant size determinant. Dev Cell 27: 345-352.

Tumbarello DA, Kendrick-Jones J, Buss F. 2013. Myosin VI and its cargo adaptors-Linking endocytosis and autophagy. J Cell Sci 126: $2561-$ 2570.

Tuxworth RI, Weber I, Wessels D, Addicks GC, Soll DR, Gerisch G, Titus MA. 2001. A role for myosin VII in dynamic cell adhesion. Curr Biol 11: $318-329$.

Tyska MJ, Mackey AT, Huang JD, Copland NG, Jenkins NA, Mooseker MS. 2005. Myosin-1a is critical for normal brush border structure and composition. Mol Biol Cell 16: 2443-2457.

Umeki N, Jung HS, Sakai T, Sato O, Ikebe R, Ikebe M. 2011. Phospholipid-dependent regulation of the motor activity of myosin X. Nat Struct Mol Biol 18: 783-788.

van Bergeijk P, Adrian M, Hoogenraad CC, Kapitein LC. 2015. Optogenetic control of organelle transport and positioning. Nature 518: 111114.

van der Velde KJ, Dhekne HS, Swertz MA, Sirigu S, Ropars V, Vinke PC, Rengaw T, van den Akker PC, Rings EH, Houdusse A, et al. 2013. An overview and online registry of microvillus inclusion disease patients and their MYO5B mutations. Hum Mutat 34: 1597-1605.

Van Gele M, Dynoodt P, Lambert J. 2009. Griscelli syndrome: A model system to study vesicular trafficking. Pigment Cell Melanoma Res 22: $268-282$.

Wagner W, Brenowitz SD, Hammer JA. 2011. Myosin-Va transports the endoplasmic reticulum into the dendritic spines of Purkinje neurons. Nat Cell Biol 13: 40-48.

Wang F, Thirumurugan K, Stafford WF, Hammer JA III, Knight PJ, Sellers JR. 2004. Regulated conformation of myosin V. J Biol Chem 279: 2333-2336.

Wang Z, Edwards JG, Riley N, Provance DWJ, Karcher R, Li XD, Davison IG, Ikebe M, Mercer JA, Kauer JA, et al. 2008. Myosin Vb mobilizes recycling endosomes and AMPA receptors for postsynaptic plasticity. Cell 135: 535-548.

Watanabe S, Mabuchi K, Ikebe R, Ikebe M. 2006. Mechanoenzymatic characterization of human myosin $\mathrm{Vb}$. Biochemistry 45: 27292738.

Watanabe TM, Tokuo H, Gonda K, Higuchi H, Ikebe M. 2010. Myosin-X induces filopodia by multiple elongation mechanism. J Biol Chem 285: 19605-19614.

Wei Z, Liu X, Yu C, Zhang M. 2013. Structural basis of cargo recognitions for class V myosins. Proc Natl Acad Sci 110: 11314-11319.

Wu X, Hammer JA. 2014. Melanosome transfer: It is best to give and receive. Curr Opin Cell Biol 29: 1-7.

Yao LL, Cao QJ, Zhang HM, Zhang J, Cao Y, Li XD. 2015. Melanophilin stimulates Myosin-5a motor function by allosterically inhibiting the interaction between the head and tail of Myosin-5a. Sci Rep 5: 10874.

Yoshimura A, Fujii R, Watanabe Y, Okabe S, Fukui K, Takumi T. 2006. Myosin-Va facilitates the accumulation of mRNA/protein complex in dendritic spines. Curr Biol 16: 2345-2351.

Yu C, Feng W, Wei Z, Miyanoiri Y, Wen W, Zhao Y, Zhang M. 2009. Myosin VI undergoes cargo-mediated dimerization. Cell 138: $537-$ 548.

Zhang H, Berg JS, Li Z, Wang Y, Lang P, Sousa AD, Bhaskar A, Cheney RE, Stromblad S. 2004. Myosin-X provides a motor-based link between integrins and the cytoskeleton. Nat Cell Biol 6: 523-531.

Zhu XJ, Wang CZ, Dai PG, Xie Y, Song NN, Liu Y, Du QS, Mei L, Ding YQ, Xiong WC. 2007. Myosin X regulates netrin receptors and functions in axonal path-finding. Nat Cell Biol 9: 184-192.

Zimmermann D, Santos A, Kovar DR, Rock RS. 2015. Actin age orchestrates myosin-5 and myosin-6 run lengths. Curr Biol 25: $2057-2062$. 


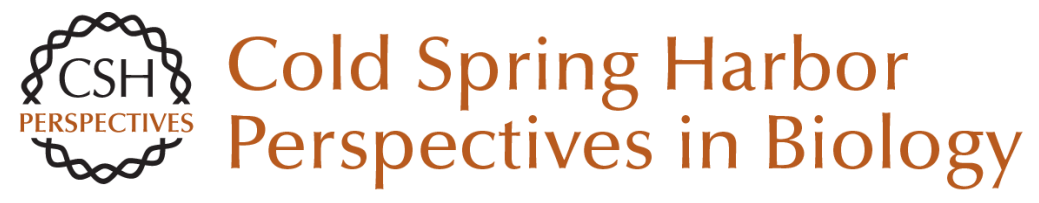

\section{Myosin-Driven Intracellular Transport}

Margaret A. Titus

Cold Spring Harb Perspect Biol 2018; doi: 10.1101/cshperspect.a021972

Subject Collection The Cytoskeleton

Microtubules and Microtubule-Associated

Proteins

Holly V. Goodson and Erin M. Jonasson

Motor Proteins

H. Lee Sweeney and Erika L.F. Holzbaur

Myosin-Driven Intracellular Transport Margaret A. Titus

The Actin Cytoskeleton and Actin-Based Motility Tatyana Svitkina

\section{Mechanical Properties of the Cytoskeleton and Cells \\ Adrian F. Pegoraro, Paul Janmey and David A. Weitz}

Intermediate Filaments and the Regulation of Cell Motility during Regeneration and Wound Healing Fang Cheng and John E. Eriksson

Intermediate Filaments and the Plasma Membrane Jonathan C.R. Jones, Chen Yuan Kam, Robert M. Harmon, et al.

Intracellular Motility of Intermediate Filaments Rudolf E. Leube, Marcin Moch and Reinhard Windoffer

\section{Overview of the Cytoskeleton from an}

Evolutionary Perspective

Thomas D. Pollard and Robert D. Goldman

Types I and II Keratin Intermediate Filaments Justin T. Jacob, Pierre A. Coulombe, Raymond Kwan, et al.

Muscle Contraction

H. Lee Sweeney and David W. Hammers

Type III Intermediate Filaments Desmin, Glial

Fibrillary Acidic Protein (GFAP), Vimentin, and

Peripherin

Elly M. Hol and Yassemi Capetanaki

Cytokinesis in Metazoa and Fungi Michael Glotzer

Ciliary Motility: Regulation of Axonemal Dynein Motors

Rasagnya Viswanadha, Winfield S. Sale and Mary

E. Porter

Actin-Based Adhesion Modules Mediate Cell Interactions with the Extracellular Matrix and Neighboring Cells

Alexia I. Bachir, Alan Rick Horwitz, W. James Nelson, et al.

Microtubule-Based Transport and the Distribution,

Tethering, and Organization of Organelles Kari Barlan and Vladimir I. Gelfand

For additional articles in this collection, see http://cshperspectives.cshlp.org/cgi/collection/

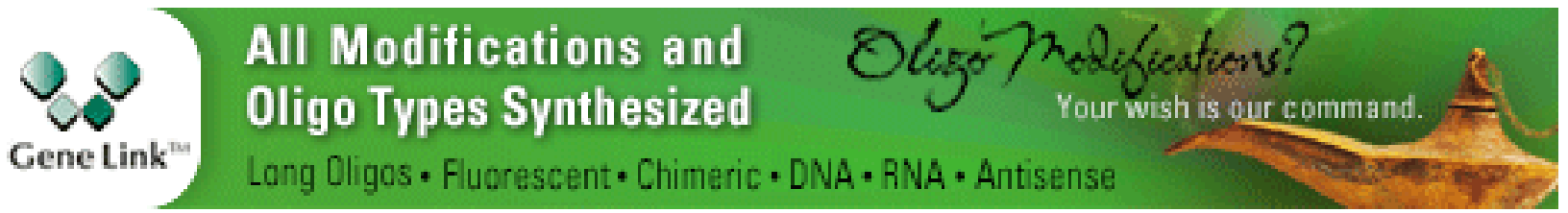

Copyright @ 2018 Cold Spring Harbor Laboratory Press; all rights reserved 
For additional articles in this collection, see http://cshperspectives.cshlp.org/cgi/collection/

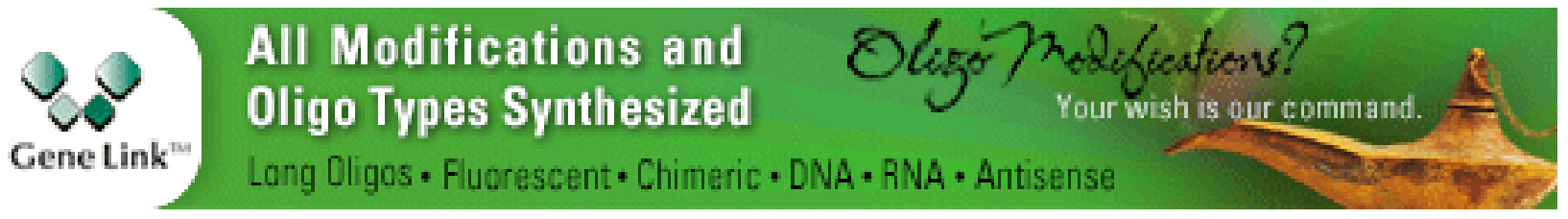

Copyright @ 2018 Cold Spring Harbor Laboratory Press; all rights reserved 